\title{
Adenosine Suppresses Cholangiocarcinoma Cell Growth and Invasion in Equilibrative Nucleoside Transporters-Dependent Pathway
}

\author{
Kornkamon Lertsuwan ${ }^{1,2}$ (D), Supathra Phoaubon ${ }^{1}$, Nathapol Tasnawijitwong ${ }^{3}$ \\ and Jomnarong Lertsuwan $4, *$ (D) \\ 1 Department of Biochemistry, Faculty of Science, Mahidol University, Bangkok 10400, Thailand; \\ kornkamon.ler@mahidol.edu (K.L.); aui_sp@hotmail.com (S.P.) \\ 2 Center of Calcium and Bone Research (COCAB), Faculty of Science, Mahidol University, \\ Bangkok 10400, Thailand \\ 3 Laboratory of Pharmacology, Chulabhorn Research Institute, Bangkok 10210, Thailand; nathapolt@cgi.ac.th \\ 4 Laboratory of Chemical Carcinogenesis, Chulabhorn Research Institute, Bangkok, 10210 Thailand \\ * Correspondence: jomnarong@cri.or.th; Tel.: +66-2553-8555 (ext. 8272)
}

Received: 25 December 2019; Accepted: 25 January 2020; Published: 27 January 2020

\begin{abstract}
Cholangiocarcinoma (CCA) is a lethal disease with increasing incidence worldwide. Previous study showed that CCA was sensitive to adenosine. Thereby, molecular mechanisms of CCA inhibition by adenosine were examined in this study. Our results showed that adenosine inhibited CCA cells via an uptake of adenosine through equilibrative nucleoside transporters (ENTs), instead of activation of adenosine receptors. The inhibition of ENTs by NBTI caused the inhibitory effect of adenosine to subside, while adenosine receptor antagonists, caffeine and CGS-15943, failed to do so. Intracellular adenosine level was increased after adenosine treatment. Also, a conversion of adenosine to AMP by adenosine kinase is required in this inhibition. On the other hand, inosine, which is a metabolic product of adenosine has very little inhibitory effect on CCA cells. This indicates that a conversion of adenosine to inosine may reduce adenosine inhibitory effect. Furthermore, there was no specific correlation between level of proinflammatory proteins and CCA responses to adenosine. A metabolic stable analog of adenosine, $2 \mathrm{Cl}$-adenosine, exerted higher inhibition on CCA cell growth. The disturbance in intracellular AMP level also led to an activation of 5' AMP-activated protein kinase (AMPK). Accordingly, we proposed a novel adenosine-mediated cancer cell growth and invasion suppression via a receptor-independent mechanism in CCA.
\end{abstract}

Keywords: purinergic signaling; cholangiocarcinoma; adenosine; equilibrative nucleoside transporters

\section{Introduction}

Short- and long-term (trophic) purinergic signaling in human has been studied in both normal and disease conditions, including in cancers. Adenosine was shown to signal through its receptors on the cell membrane [1,2]. In addition, adenosine was reported to be transported into cytoplasm via equilibrative nucleoside transporters (ENTs) [3-5]. There are four subtypes of adenosine receptors in mammalian cells, namely A1, A2a, A2b and A3 [6,7]. Their activation could lead to an alteration of cAMP production [8-10]. Purinergic signaling regulates many physiological processes based on receptor subtypes and the concentration of their agonist(s). On the other hand, adenosine that was imported into cytoplasm via ENTs could be phosphorylated into AMP. This could disrupt AMP/ATP balance leading to an activation of AMP-activated protein kinase (AMPK) and an alteration in cell metabolism [11]. Furthermore, accumulation of intracellular adenosine could lower the ratio of S-adenosylmethionine 
(SAM)/S-adenosylhomocysteine (SAH) by increasing SAH level from a combination of adenosine with homocysteine. This could lead to hypomethylation of DNA [12].

A high concentration of adenosine has deleterious effects on various types of cancer, including hepatoma, pleural mesothelioma, prostate cancer and colon cancer [3,13-15]. Adenosine induced apoptosis and cell cycle arrest in human ovarian cancer cells (HEY, A2780 and its cisplatin-resistant subline A2780CisR) at $\mathrm{IC}_{50}$ around $700-900 \mu \mathrm{M}$. It also enhanced cisplatin sensitivity in the aforementioned cell lines [16]. Interestingly, cholangiocarcinoma (CCA) was more sensitive to adenosine than these types of cancer and had an $\mathrm{IC}_{50}$ around $250 \mu \mathrm{M}$ [17].

CCA is a lethal cancer arisen from bile duct epithelial cells. The incidence of CCA is highest in the northeastern provinces of Thailand where 165.7 out of every 100,000 males were diagnosed with CCA [18]. Moreover, the increasing incidence of this cancer has been reported worldwide [19]. Therefore, novel treatment options are urgently needed due to the irresponsiveness of the disease to current chemotherapeutic drugs [20,21]. Inflammation, pesticide-induced liver and bile duct damage, hepatitis B virus infection, liver fluke infection [22-26] and smoking and alcohol consumption [18] also contribute to CCA progression. Several inflammatory pathways have been reported to be involved in CCA progression, such as NF- KB, Notch and iNOS pathways [27-32]. Accordingly, inflammatory pathways have also been proposed as therapeutic targets for CCA [33,34]. Among the inflammation regulating proteins, many studies have shown an involvement of protein kinase CK2 in CCA malignancy [35-37].

Recently, we have reported an inhibitory effect of adenosine on two CCA cell lines and one immortalized cholangiocyte (imCho) cell line. We have demonstrated that CCA cells were significantly more sensitive to adenosine than the imCho cells [17]. The $\mathrm{IC}_{50}$ values of adenosine on CCA cells were around $250 \mu \mathrm{M}$, much lower than on other types of cancer (1-4 mM) [3,13]. Accordingly, adenosine could be a good candidate as a novel therapeutic compound for CCA. In this study, six CCA cell lines and two imCho cell lines from both Asian and Caucasian origins were used. Among the CCA cell lines used, three CCA cell lines originated from Thai patients living in northeastern provinces where CCA is endemic.

In the present study, adenosine showed its inhibitory effects on CCA cell lines rather than imCho cells. CCA cells were shown to respond to adenosine at different degrees, leading to the classification of CCA cells into adenosine-sensitive, adenosine-resistant and unresponsive or uncalculatable (UnCal) groups. We also showed that adenosine inhibited CCA cell invasion in a receptor-independent mechanism.

\section{Results}

\subsection{Adenosine Suppressed CCA Cell Growth with Minimal Effect on Immortalized Cholangiocytes}

Cell viability assay was performed by using MTT assay to examine the sensitivity of adenosine on CCA and imCho cell growth. MMNK-1 was used to represent immortalized cholangiocyte (imCho) cell lines. HuCCA-1, RMCCA-1, KKU-100, KKU-055 and KKU-213 cell lines represented CCA cell lines originating from Thai patients. We observed that these cell lines had different sensitivities to adenosine. The imCho cell lines, MMNK-1, was more resistant as compared to most CCA cell lines, except KKU-100 (Figure 1a,d and Table 1). The $\mathrm{IC}_{50}$ of adenosine on MMNK-1 could not be calculated and was designated as "UnCal" since adenosine was unable to suppress the growth under $50 \%$ as compared to the vehicle control group during the 4-day period of the experiment (Figure 1a). Interestingly, other CCA cell lines, HuCCA-1, RMCCA-1 and KKU-213 were sensitive to adenosine with the $\mathrm{IC}_{50}$ around 250-320 $\mu \mathrm{M}$ (Figure 1b, c and f and Table 1). However, among CCA cell lines, Northeastern Thai origin cell lines, including KKU-100 and KKU-055, were resistant to adenosine. KKU-100 was also designated as "UnCal" since its $\mathrm{IC}_{50}$ was unable to be calculated in this experiment, and KKU-055 was resistant to adenosine with the $\mathrm{IC}_{50}$ at $1000 \mu \mathrm{M}$ (Figure 1e and Table 1). According to the $\mathrm{IC}_{50}$, these cell lines were categorized into adenosine-sensitive, adenosine-resistant and UnCal groups according to statistical 
analysis (Student's t-test) (Figure 1g). HuCCA-1, RMCCA-1 and KKU-213 were designated as sensitive (S). On the other hand, KKU-055 was designated as resistant (R), and KKU-100 and MMNK-1 were classified as UnCal. (Figure 1g).

In addition to MTT cell viability assay, the effect of adenosine on cell reproductive viability was also examined by utilizing clonogenic assay. The cells were treated with $500 \mu \mathrm{M}$ adenosine for 2 weeks before the colonies were counted. Treatments were refreshed three times a week. The imCho cell line, MMNK-1, and adenosine-resistant CCA cell lines, KKU-100 and KKU-055, showed no reduction in colony number after 2 weeks of culture with $500 \mu \mathrm{M}$ adenosine (Figure 2a). Conversely, adenosine was able to reduce the number of colonies in HuCCA-1, RMCCA- 1 and KKU-213 by 50\%, 60\% and 45\%, respectively (Figure 2a).
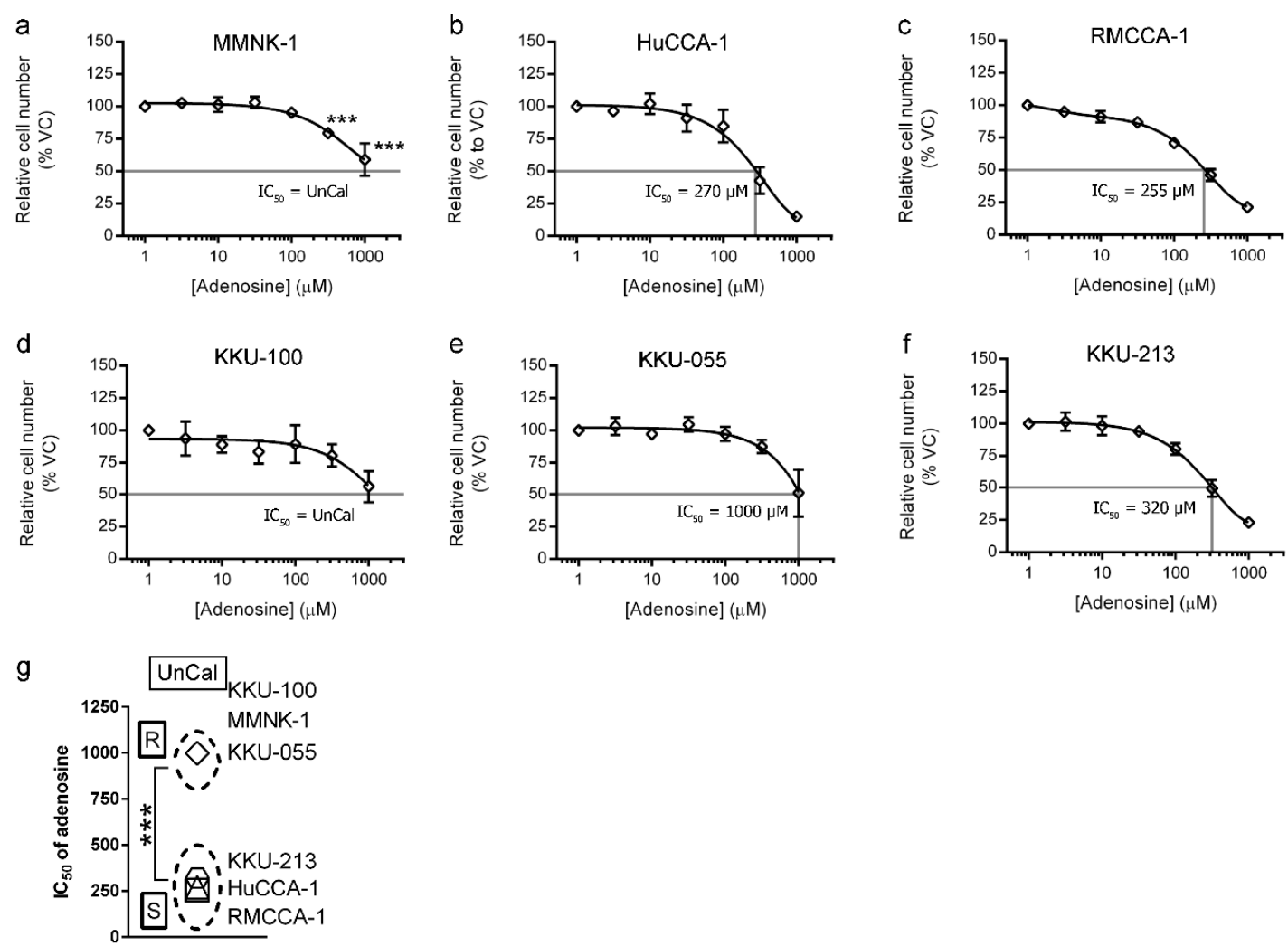

Figure 1. Four-day cell viability MTT assay was used to examine adenosine sensitivity on cholangiocarcinoma (CCA) and immortalized cholangiocyte (imCho) cell lines. (a-f) Adenosine inhibited CCA and imCho cell growth in a dose-dependent manner. (g) Cell lines were classified into adenosine-sensitive group, adenosine-resistant group and unresponsive or uncalculatable group, of which IC $_{50}$ was uncalculatable. Statistical analysis in (g) was Student's $t$-test. VC; vehicle control, S; sensitive, R; resistant, UnCal; uncalculatable, ${ }^{* * *} p<0.001$. All experiments were performed using at least three biological replicates with internal triplicate. Graphs are plotted as mean \pm SD. 
Table 1. $\mathrm{IC}_{50}$ and $\mathrm{pIC}_{50}$ of the adenosine on cholangiocarcinoma (CCA) and immortalized cholangiocyte (imCho) cell lines. UnCal; uncalculatable.

\begin{tabular}{|c|c|c|c|c|c|c|c|}
\hline Cell Line & $\begin{array}{l}\text { Cell } \\
\text { Type }\end{array}$ & Type & Origin & $\begin{array}{l}\text { Doubling } \\
\text { Time (h) }\end{array}$ & Sex & $\begin{array}{c}\text { IC }_{50} \text { of the } \\
\text { Adenosine }(\mu \mathrm{M})\end{array}$ & $\mathrm{pIC}_{50}$ \\
\hline MMNK-1 & imCho & & Japanese & 41.43 & Male & UnCal & UnCal \\
\hline HuCCA-1 & \multirow{5}{*}{ CCA } & intrahepatic & \multirow{2}{*}{ Thai } & 43.95 & Male & 270 & 3.57 \\
\hline RMCCA-1 & & peripheral & & 49.40 & Male & 255 & 3.59 \\
\hline KKU-100 & & extrahepatic & \multirow{3}{*}{$\begin{array}{c}\text { Thai } \\
\text { (Northeastern) }\end{array}$} & 70.48 & Female & UnCal & UnCal \\
\hline KKU-055 & & intrahepatic & & 97.40 & Male & 1000 & 3.00 \\
\hline KKU-213 & & intrahepatic & & 34.40 & Male & 320 & 3.49 \\
\hline
\end{tabular}
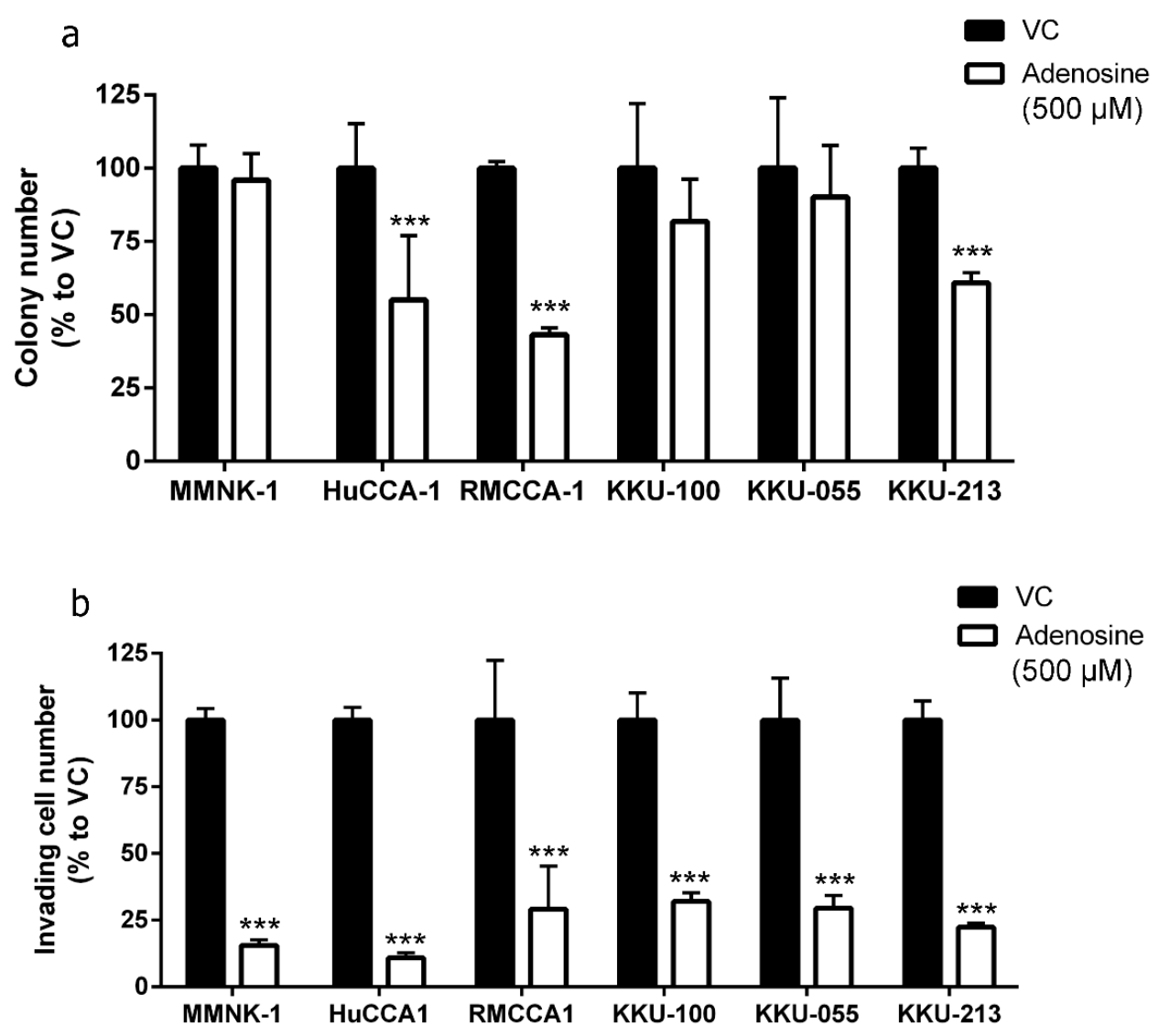

Figure 2. Adenosine inhibited cholangiocarcinoma (CCA) colony formation and cell invasion. (a) Adenosine reduced number of colony formation in adenosine-sensitive CCA cell lines after 2 weeks. (b) Adenosine significantly reduced number of invading cells through Matrigel in all cell lines tested, despite their sensitivity to adenosine in cell viability and colony formation assay. VC; vehicle control, ${ }^{* * *} p<0.001$. All experiments were performed using at least three biological replicates with internal triplicate. Graphs are plotted as mean \pm SD.

\subsection{Adenosine Inhibited CCA Cell Invasion}

A major problem resulting from many types of cancer, including CCA, is metastasis. We further investigated the effect of adenosine on cell invasion through Matrigel. Interestingly, adenosine reduced cell invasion in all CCA and imCho cell lines tested (Figure $2 b$ ) regardless of its sensitivity in the cell viability assay (Figure 1). In the presence of adenosine, imCho MMNK-1 cell invasion was reduced to $15.55 \%$ (Figure 2b). HuCCA-1 was the most sensitive cell line in invasion assay and was suppressed to $10.90 \%$ in the adenosine-treated group (Figure $2 b$ ). In addition, RMCCA-1, KKU-100 and KKU-055 cell 
invasion were suppressed to approximately $30 \%$ by adenosine. Finally, KKU-213 cell invasion was decreased to $23.36 \%$ (Figure $2 \mathrm{~b}$ ).

\subsection{Inhibitory Effect of Adenosine on CCA Cell Growth and Invasion Was Receptor-Independent}

Since adenosine could affect cells by both activating the receptors and being transported into cytoplasm via its transporters, we next investigated the mechanism underlying adenosine inhibition on CCA cells. The pan antagonists of adenosine receptors, caffeine (for A1, A2a and A2b) and CGS-15943 (for A1, A2a, A2b and A3), along with a pan inhibitor of equilibrative nucleoside transporters (ENTs), S-(4-nitrobenzyl)-6-thioinosine (NBTI), were introduced to adenosine-sensitive CCA cells with or without the presence of adenosine.

We demonstrated that $500 \mu \mathrm{M}$ adenosine inhibited cell growth to $55 \%$ and $50 \%$ in HuCCA-1 and RMCCA-1, respectively (Figure 3a). Interestingly, addition of caffeine (Figure 3a) or CGS-15943 (Figure 3b) to adenosine was unable to reduce an inhibitory effect of adenosine on cell viability (MTT assay) in these three cell lines. In contrast, introduction of $10 \mu \mathrm{M}$ NBTI was able to reduce inhibitory effect of adenosine on all cell lines tested (Figure 3c). Cell viability was increased in CCA cells treated with adenosine together with NBTI as compared to CCA cells treated with adenosine alone from approximately $50 \%$ to $75 \%$ in both HuCCA-1 and RMCCA-1 (Figure 3c).

Furthermore, both $500 \mu \mathrm{M}$ caffeine and $5 \mu \mathrm{M}$ CGS-15943 could not reduce an inhibitory effect of adenosine on CCA cell invasion in all CCA cell lines tested (Figure 4a). The invading cell number in caffeine/CGS-15943 plus adenosine-treated group remained the same as in the vehicle control plus adenosine-treated group in all cell lines tested (Figure 4a). Conversely, $10 \mu \mathrm{M}$ NBTI was able to significantly alleviate an inhibitory effect of adenosine on CCA cell invasion in all cell lines tested. Inhibitory effects of adenosine on CCA cell invasion was recovered from $11.4 \%$ to $61.4 \%$ in HuCCA-1, from $30.0 \%$ to $68.2 \%$ in RMCCA- 1 and from $22.4 \%$ to $72.3 \%$ in KKU-213 in the presence of NBTI (Figure 4a). In addition, the results showed that NBTI also suppressed adenosine effects on cell migration in $2 \mathrm{D}$ tissue culture plate. The inhibitory effect was lowered by approximately $20 \%$ after $18 \mathrm{~h}$ of adenosine treatment together with NBTI (Figure $4 \mathrm{~b}, \mathrm{c}$ ).

In addition, we demonstrated that intracellular adenosine level was increased after $500 \mu \mathrm{M}$ adenosine treatment in all CCA cell lines tested. Intracellular adenosine was increased to 9.1-, 9.5and 11.0-fold higher than untreated cells before reaching a plateau at $30 \mathrm{~min}$ (Figure $4 \mathrm{~d}$ ). Therefore, we concluded that adenosine suppressed CCA cell invasion and migration via a receptor-independent but transporter-dependent mechanism. 

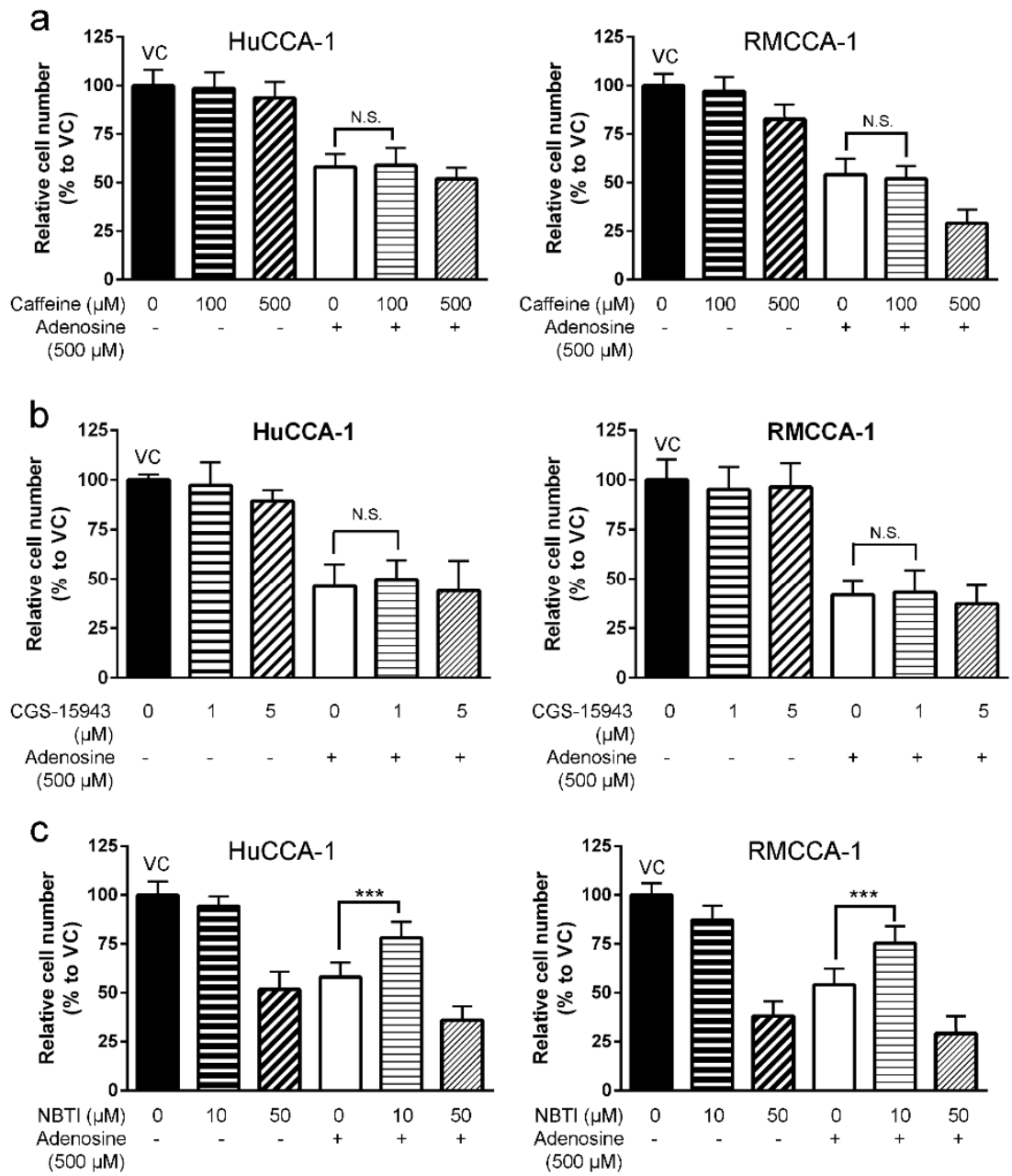

Figure 3. Adenosine inhibited CCA cell growth in a receptor-independent mechanism. (a) Caffeine, an antagonist for A1, A2a and A2b receptors, showed no significant effect on adenosine-mediated CCA cell growth suppression in viability MTT assay. (b) CGS-15943, a pan antagonist of adenosine receptors, showed no significant effect on adenosine-mediated CCA cell growth suppression in viability MTT assay. (c) Inhibitory effect of adenosine on cell growth subsided when $10 \mu \mathrm{M}$ (4-nitrobenzyl)-6-thioinosine (NBTI), a broad inhibitor of equilibrative nucleoside transporters (ENTs), was applied $1 \mathrm{~h}$ prior to adenosine treatment. VC; vehicle control, N.S.; not significant, ${ }^{* * *} p<0.001$. All experiments were performed using at least three biological replicates with internal triplicate. Graphs are plotted as mean \pm SD. 

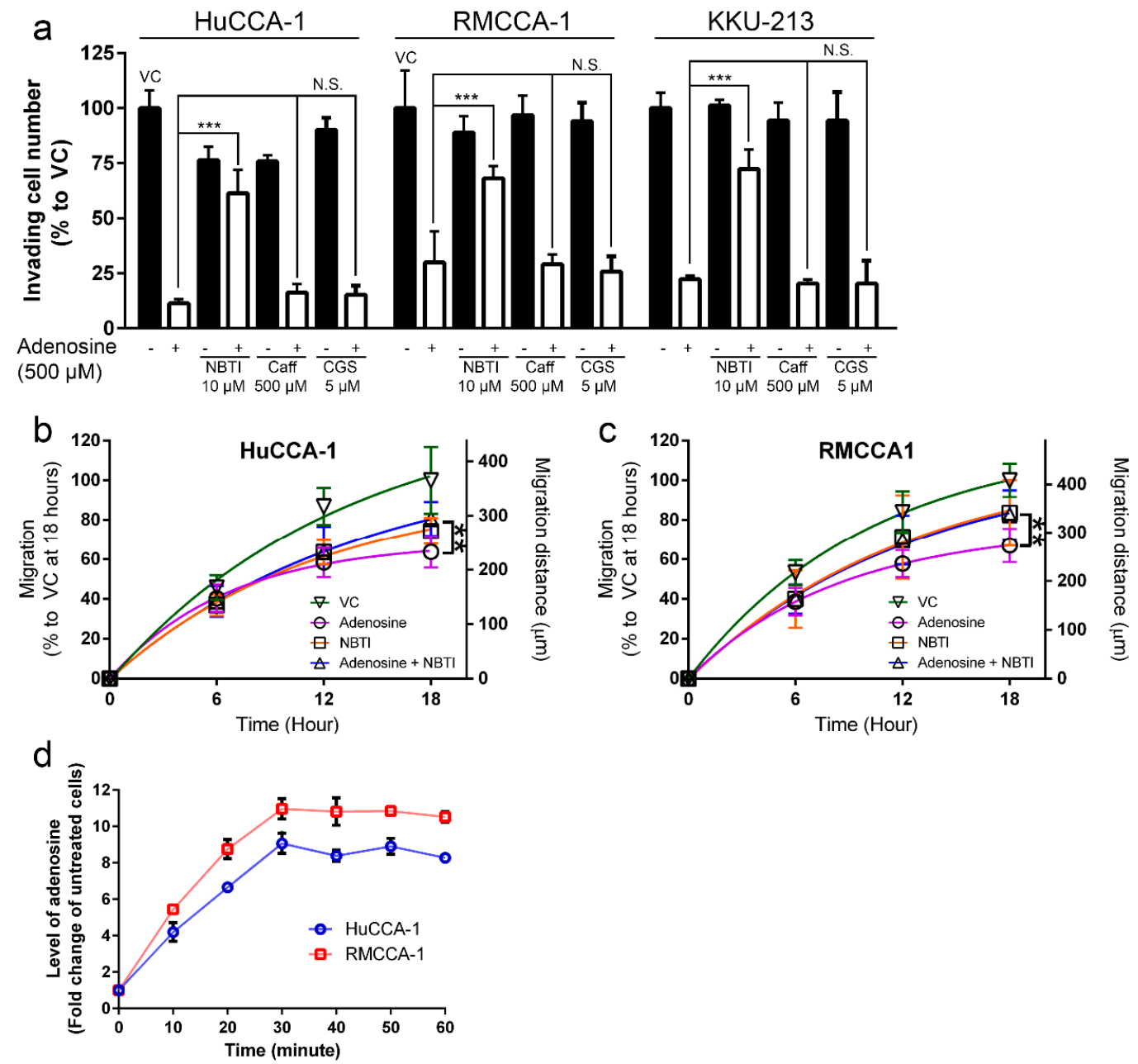

Figure 4. Adenosine inhibited cholangiocarcinoma (CCA) cell motility in a receptor-independent mechanism. (a) Adenosine suppressed CCA cell invasion through Matrigel in a receptor-independent mechanism. Caffeine and CGS-15943, pan antagonists of adenosine receptors, showed no significant effect on adenosine-mediated CCA cell invasion suppression. Inhibitory effect of adenosine on cell invasion was reduced when $10 \mu \mathrm{M}$ (4-nitrobenzyl)-6-thioinosine (NBTI), a broad inhibitor of equilibrative nucleoside transporters (ENTs), was applied $1 \mathrm{~h}$ prior to adenosine treatment. (b-c) Adenosine also suppressed CCA cell migration in 2D culture in a receptor-independent mechanism. NBTI at $10 \mu \mathrm{M}$ was able to reduce adenosine-mediated inhibitory effect on CCA cell migration in wound-healing assay. (d) Intracellular adenosine level increased after $500 \mu \mathrm{M}$ adenosine treatment. VC; vehicle control, Caff; caffeine, CGS; CGS-15943, N.S.; not significant, ${ }^{* *} p<0.01,{ }^{* * *} p<0.001$. All experiments were performed using at least three biological replicates with internal triplicate. Graphs are plotted as mean $\pm \mathrm{SD}$.

\subsection{Correlation between Level of Inflammatory Proteins and Adenosine Sensitivity in CCA Cell Lines was not Observed}

Our data demonstrated that imCho cell lines (MMNK-1) and CCA cell lines (KKU-100 and KKU-055) were more resistant to adenosine as compared to other CCA cell lines (Figures 1 and 2). We further investigated the underlying mechanism that makes most CCA cell lines sensitive to adenosine; a few CCA cell lines and imCho cell lines were resistant. The levels of proinflammatory molecules were investigated because inflammation was shown to be involved in CCA progression and aggressiveness [38-40]. Levels of nuclear factor- $\mathrm{kB}(\mathrm{NF}-\mathrm{kB})$, cyclooxygenase 2 (COX2), inducible nitric oxide synthase (iNOS) and Notch1 were examined in five CCA cell lines and one imCho cell lines (Figure $5 a, b)$. The level of all aforementioned proteins showed no specific correlation to adenosine 
sensitivity in CCA cell lines. Furthermore, CCA cell lines that were adenosine-resistant grew slower and had longer doubling time as compared to CCA cell lines that were sensitive to adenosine (Table 1). Doubling times for KKU-100 and KKU-055, which were adenosine-resistant, were approximately 70 and $97 \mathrm{~h}$, respectively; other CCA cell lines had shorter doubling times of approximately $40 \mathrm{~h}$ (Table 1 ). Nonetheless, the imCho cell line, MMNK-1, was resistant to adenosine but had doubling times of around $40 \mathrm{~h}$ (Table 1), which is comparable to adenosine-sensitive CCA cell lines. These data suggested that adenosine did not solely inhibit any fast-growing cells, but its inhibitory effects depended on a specific molecular mechanism not yet revealed.
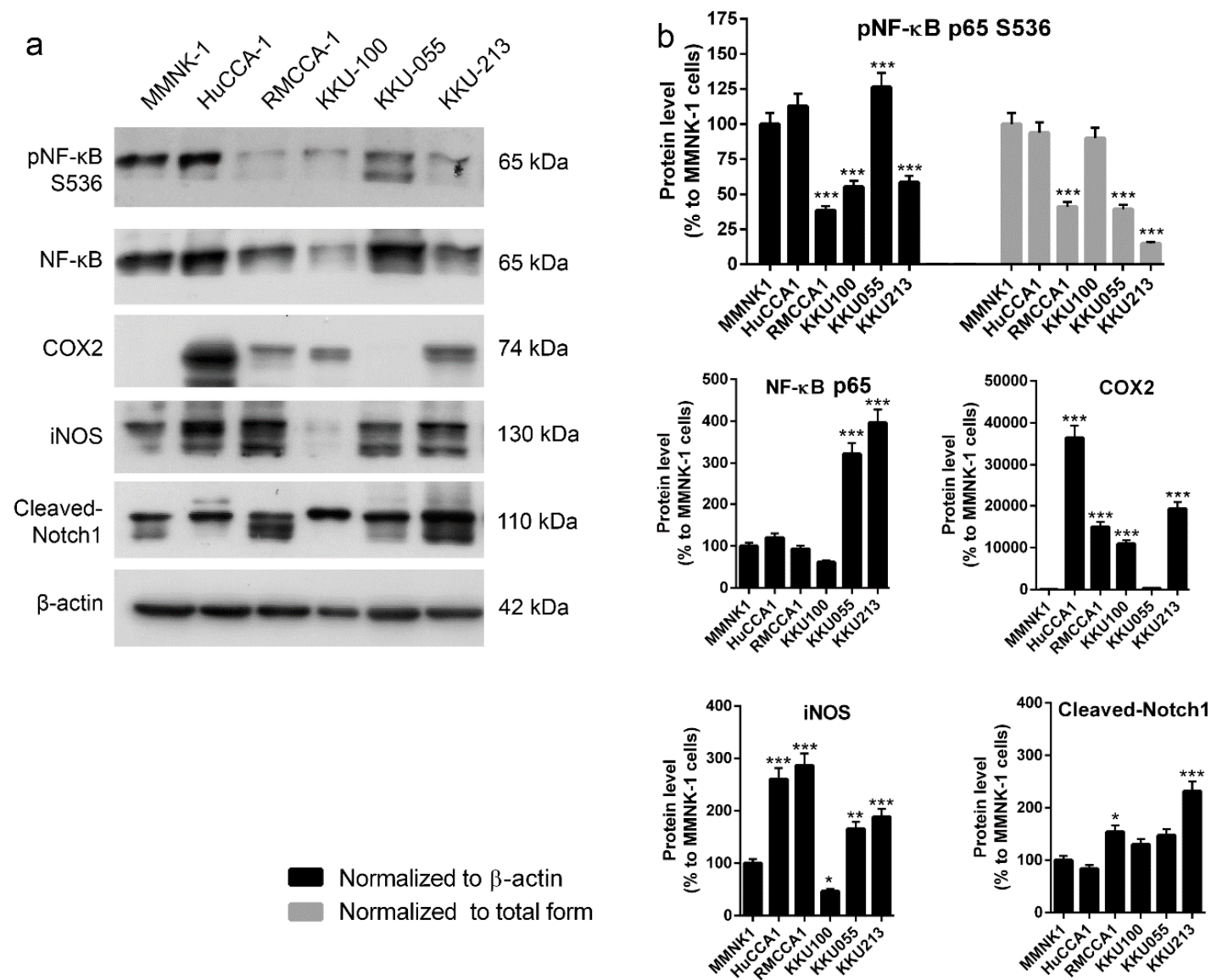

Figure 5. Levels of proteins in inflammatory pathways in cholangiocarcinoma (CCA) and immortalized cholangiocyte cell lines were investigated. (a) There is no correlation between level of inflammatory proteins and adenosine sensitivity in CCA cell lines. (b) Semiquantitative data of protein levels in (a) ${ }^{*} p<0.05,{ }^{* *} p<0.01,{ }^{* * *} p<0.001$. All experiments were performed using at least three biological replicates with internal triplicate. Graphs are plotted as mean \pm SD.

\subsection{A Conversion of Adenosine to AMP Is Required for the Inhibition}

We have demonstrated that adenosine treatment led to increased intracellular adenosine and could potentially be transported into CCA cells by ENTs (Figures 3 and 4). Therefore, we further investigated the possible metabolic phases of adenosine once it was transported into CCA cells. In normal cells, intracellular adenosine could be converted to AMP by the activity of adenosine kinase to regenerate the energy carrier molecules (ADP and ATP, subsequently) and to serve as a precursor for nucleotide synthesis [41]. On the other hand, adenosine could also be deaminated by adenosine deaminase to inosine, which can also be used as another precursor in nucleotide synthesis [41]. Hence, to validate the roles of adenosine kinase, metabolic stable adenosine (2Cl-adenosine) and inosine were further tested to elucidate the potential metabolic phases of intrasellar adenosine in adenosine-treated CCA cells. 
Adenosine kinase inhibitor ABT-702 was used in the experiment to determine the requirement of this enzyme in adenosine-mediated CCA cell suppression. Our results showed that ABT-702 reduced an inhibitory effect of adenosine on CCA cell viability in MTT assay (Figure 6a). Higher cell viability was observed in HuCCA-1 (from 53.6\% in adenosine-treated group to $78.7 \%$ with a presence of $30 \mu \mathrm{M}$ ABT-702) and RMCCA-1 (from 59.9\% in adenosine-treated group to $91.8 \%$ with a presence of $30 \mu \mathrm{M}$ ABT-702) (Figure 6a). Therefore, the activity of adenosine kinase is required for adenosine-induced CCA cell suppression. As many studies showed that phosphorylated AMPK $\alpha$ was increased when the ratio between intracellular AMP + ADP and ATP (AMP + ADP/ATP) was higher [42], the increased level of AMP as indicated by the increased level of phosphorylated AMPK $\alpha$ was examined. Our results showed that phosphorylated AMPK $\alpha$ was increased to $153 \%$ and $135 \%$ in HuCCA-1 and RMCCA-1, respectively (Figure 6b,c). These results indicated that adenosine-induced CCA cell suppression mechanism requires adenosine kinase activity. In other words, adenosine, which was imported into CCA cells, was phosphorylated into AMP as indicated by the requirement of adenosine kinase activity and the increase of phosphorylated AMPK $\alpha$.

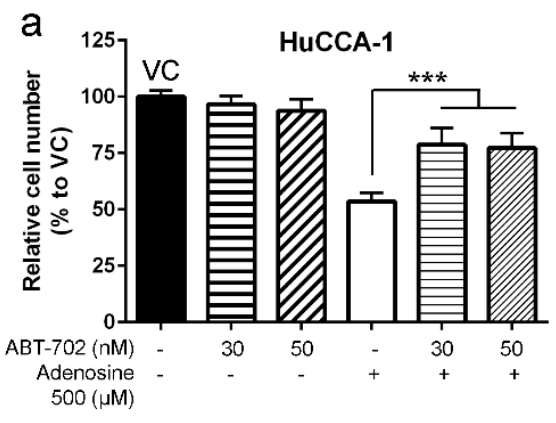

b
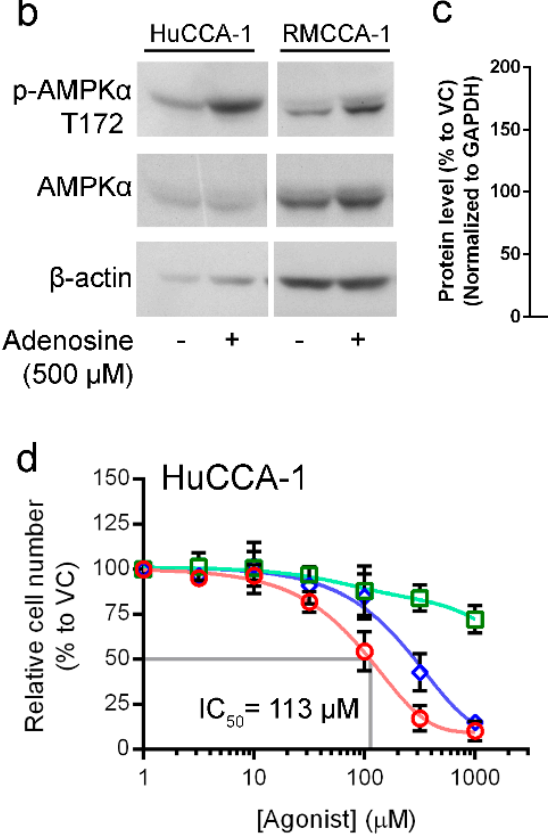

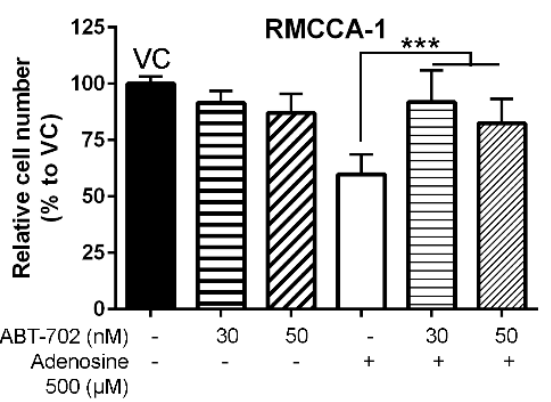

C

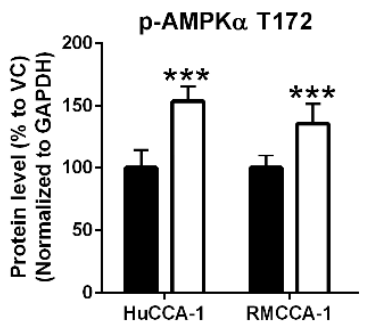

DC $\square 500 \mu \mathrm{M}$ Adenosine AMPK $\alpha$

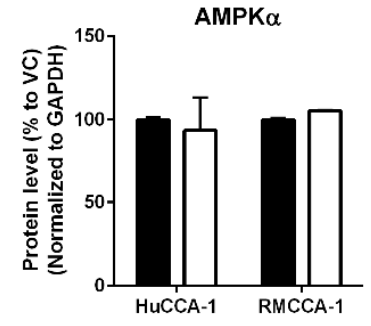

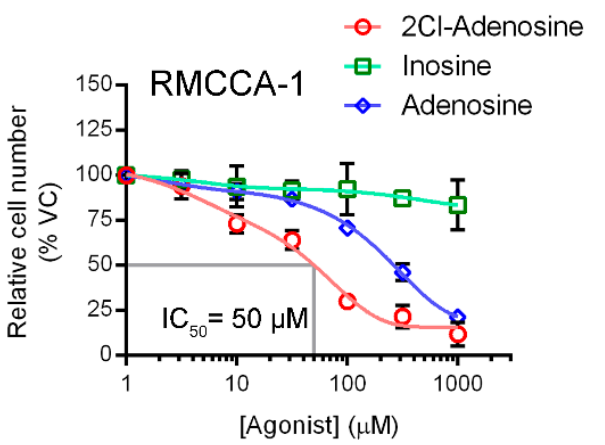

Figure 6. Adenosine inhibited CCA cells through a conversion to AMP. (a) MTT assay showed CCA cell viability after $24 \mathrm{~h}$ adenosine treatment with or without ABT-702, an inhibitor of AMP-producing 
enzyme: adenosine kinase. ABT-702 was able to reduce adenosine's inhibitory effect. (b) Adenosine treatment increased phosphorylated form of AMPK $\alpha$ after $24 \mathrm{~h}$ of the treatment. (c) Semiquantitative data of protein levels in (b). (d) 2-Chloroadenosine (2Cl-adenosine) also inhibited CCA cell lines in MTT viability assay but inosine had only little effect on CCA cell viability. VC; vehicle control, ${ }^{* * *} p<0.001$. All experiments were performed at least three biological replicates with internal triplicate. Graphs were plotted as mean $\pm \mathrm{SD}$.

Furthermore, to confirm the AMP-mediated mechanism in adenosine-induced CCA cell inhibition, 2-chloroadenosine (2Cl-adenosine) and inosine were tested for their potential inhibitory effect on CCA cells. $2 \mathrm{Cl}$-adenosine is a metabolically stable analog of adenosine, which has been shown to preferably change to AMP rather than inosine. Our results revealed that $2 \mathrm{Cl}$-adenosine had higher inhibitory effect on CCA cells as compared to adenosine, suggesting the preferable path of adenosine-induced CCA cell inhibition via AMP formation (Figure 6d). Its IC 50 values on HuCCA-1 and RMCCA-1 were 113 and $50 \mu \mathrm{M}$, respectively (Figure $6 \mathrm{~d}$ ). In contrast, inosine had only minimal inhibitory effect on CCA cells. Inosine concentration as high as $1000 \mu \mathrm{M}$ reduced HuCCA-1 and RMCCA-1 only to $72.2 \%$ and $83.6 \%$ (Figure $6 \mathrm{~d}$ ). The results indicated that inosine was not likely to play a role in CCA cell suppression by adenosine.

\section{Discussion}

Five CCA and one imCho cell lines were examined for their sensitivity to adenosine and was categorized into three groups: adenosine-sensitive group $\left(\mathrm{IC}_{50}\right.$ between $\left.250-320 \mu \mathrm{M}\right)$, adenosine-resistant group $\left(\mathrm{IC}_{50} 1000 \mu \mathrm{M}\right)$ and uncalculatable (UnCal) group. The UnCal groups were the cells for which an $\mathrm{IC}_{50}$ was unable to be calculated because adenosine was unable to suppress the growth under $50 \%$ as compared to the vehicle control group during the 4-day period of the experiment. Interestingly, adenosine was also able to suppress cell invasion through Matrigel in all cell lines regardless to their sensitivity in cell viability MTT assay. We further investigated the potential molecular pathways underlying this inhibition and have demonstrated that adenosine inhibited CCA cells in a receptor-independent mechanism. Some of these cell lines including HuCCA-1, RMCCA-1 and MMNK-1 were reported to not express adenosine receptor genes, [17] while other cell lines expressed some adenosine receptor genes (Figure S1 and Table S1). Furthermore, expression of ENPP1-3 and ENTPD1-3 (CD39 family), which convert ATP to AMP [43,44], was ubiquitous. At least one of the ENPP or ENTPD members was expressed on CCA and imCho cell lines (Figure S1 and Table S1). Accordingly, the presence of adenosine receptors and adenosine-producing enzymes and adenosine sensitivity did not correlate. In addition, pan adenosine receptor antagonist, caffeine and CGS-15943 failed to rescue CCA cells from adenosine inhibitory effects (Figures 3 and 4). Previous study showed that adenosine could also be transported into cytoplasm via equilibrative nucleoside transporters (ENTs). By using ENTs inhibitor, S-(4-nitrobenzyl)-6-thioinosine (NBTI), our results showed that NBTI was able to rescue CCA from adenosine (Figures 3 and 4). This suggested the transporter-dependent cancer inhibition, similar to what has previously been reported in colon and cervical cancers $[3,4]$. Since the activity of ENTs was required in CCA cell inhibition by adenosine, intracellular level of adenosine in CCA cells after adenosine treatment was examined. The results showed that exogenous treatment of adenosine of CCA cells increased the level of intracellular adenosine (Figure 4e).

It has been reported that intracellular adenosine could be converted to other metabolites, including AMP and inosine. Adenosine could be phosphorylated to AMP by the activity of adenosine kinase, or it could be converted to inosine by the activity of adenosine deaminase as mentioned previously [41]. Accordingly, the potential metabolic change of adenosine in adenosine-mediated CCA cell suppression was elucidated. As the major enzyme to phosphorylate adenosine to AMP, the contribution of adenosine kinase in adenosine-mediated CCA cell suppression was examined. The results showed that adenosine's inhibitory effects on CCA cells were subsided in the presence of adenosine kinase inhibitor, indicating its important role in adenosine-mediated CCA cell suppression (Figure 6a). Further, the increased level of intracellular AMP was also indirectly shown by the level of phosphorylated AMPK $\alpha$ 
in CCA cells exposed to adenosine. These suggested the potential mechanism of CCA cell suppression by adenosine through AMP production by adenosine kinase. To further confirm this speculation, $2 \mathrm{Cl}$-adenosine, which is a metabolically stable analog of adenosine, was used as representative of adenosine that was mainly converted to AMP as previously reported [45]. Our results showed a higher inhibitory effect of $2 \mathrm{Cl}$-adenosine on CCA cell viability as compared to adenosine. In addition, inosine, another metabolic product of adenosine, had minimal effect on CCA cell viability. These data suggested that adenosine exerted its inhibitory effect when it is not metabolically converted into inosine, but rather converted to AMP.

Generally, chemotherapeutic drugs tend to be more effective on fast-growing cells regardless of cell type (cancerous or noncancerous). This causes deleterious side effects, including hair loss, nausea and diarrhea. Interestingly, adenosine had much less deleterious effects on noncancerous cell growth despite their fast-growing characteristic (Figure 1a and Table 1). Therefore, adenosine was shown to be a strong candidate for the novel therapeutics for CCA. Further experiments in animals are needed to assess the tolerance and side effects of adenosine in vivo.

In summary, our study revealed the therapeutic potential and differential responses of adenosine on CCA cells. The novel adenosine-mediated cancer cell suppression through a receptor-independent but nucleoside-transporter-dependent mechanism in CCA cells was elaborated. Extracellular adenosine treatment led to increased intracellular adenosine, which was later phosphorylated to AMP by adenosine kinase and an activation of AMPK.

\section{Materials and Methods}

\subsection{Cell Culture}

Characteristics of all cell lines used in this study are described in Table 1. Three CCA cell lines, KKU-100, KKU-055 and KKU-213, were established as previously described [46] and were purchased from Japanese Collection of Research Bioresources (JCRB) Cell Bank (Osaka, Japan). The imCho cell line, MMNK-1, was also purchased from JCRB Cell Bank. HuCCA-1 was established and kindly provided by Stitaya Sirisinha at Chulabhorn Research Institute [47]. RMCCA-1 cell line was established from a peripheral CCA specimen surgically obtained from a Thai patient and was kindly provided by Rutaiwan Tohtong at Mahidol University [48]. All cell lines were maintained in Dulbecco's modified Eagle's medium (DMEM) (SH30243.02, Hyclone, Pittsburgh, PA, USA) supplemented with 10\% fetal bovine serum (FBS) (10270-106 Brazil origin, Gibco, Grand Island, NY, USA) and 1\% MEM non-essential amino acid (1140-050, Gibco). All media were supplemented with 1\% penicillin/streptomycin (15140-122, Gibco). All cell lines were maintained at $37^{\circ} \mathrm{C}$ with $5 \% \mathrm{CO}_{2}$.

\subsection{Cell Viability MTT Assay}

Cells were plated in tissue culture treated 96-well plates. After overnight adhesion to the plate, the treatment groups were incubated with adenosine (A4036, Sigma Aldrich) at 3.16 to $1000 \mu \mathrm{M}$ with a half $\log$ increment. Media were changed and new treatments were added on day 2. After 4 days, MTT reagent (M6494, Fisher Scientific, Hampton, NH, United States) was added to the final concentration of $0.5 \mathrm{mg} / \mathrm{mL}$ in $100 \mu \mathrm{L}$ culture media and incubated for $2.5 \mathrm{~h}$ at $37^{\circ} \mathrm{C}$. Fifty microliters of stop solution $\left(10 \%\right.$ SDS in $50 \%$ dimethylformamide in $\left.\mathrm{dH}_{2} \mathrm{O}\right)$ was added and mixed thoroughly before reading the absorbance at $560 \mathrm{~nm}$ on Multimode Plate Reader Victor Nivo (Perkin Elmer). The following reagents, S-(4-nitrobenzyl)-6-thioinosine (NBTI) (sc-200117, Santa Cruz Biotechnology, Dalla, TX, USA), caffeine (C 5-3, Sigma-Aldrich, St. Louis, MO, USA), CGS-15943 (C199, Sigma-Aldrich) or ABT-702 (2372, Tocris, Bristol, UK), were added according to the experimental design.

\subsection{Clonogenic Assay}

Cells were plated at 500 cells per well in tissue-culture-treated 24-well plate and allowed to adhere overnight. Adenosine (A4036, Sigma Aldrich) at $500 \mu \mathrm{M}$ was added and incubated for 2 weeks. Media 
and treatment were changed regularly, three times per week. After 2 weeks, cells were stained with $0.5 \%(w / v)$ crystal violet in $12 \%(v / v)$ glutaraldehyde in water for $30 \mathrm{~min}$ at $23{ }^{\circ} \mathrm{C}$. Cells were rinsed with $\mathrm{dH}_{2} \mathrm{O}$ and manually counted under microscope. A group of 100 cells or more was counted as one colony.

\subsection{Cell Invasion Assay}

Eight-micrometer polycarbonate membrane transwell inserts (353097, Falcon, New York, NY, USA) were coated with $50 \mu \mathrm{L}$ of a 1:10 mixture of Matrigel ${ }^{\mathrm{TM}}$ (356234, BD Biosciences, San Jose, CA, USA) in serum-free medium. Then, it was allowed to congeal at $37^{\circ} \mathrm{C}$ for $30 \mathrm{~min}$. A total of $5 \times 10^{4}$ cells were added to the insert in serum-free medium. The bottom well was filled with complete medium. Treatment of $500 \mu \mathrm{M}$ adenosine (A4036, Sigma Aldrich) was added in both top and bottom chambers. Ten micromolars of S-(4-nitrobenzyl)-6-thioinosine (NBTI) or $500 \mu \mathrm{M}$ of caffeine or $5 \mu \mathrm{M}$ of CGS-15943 were added $1 \mathrm{~h}$ prior to adenosine (A4036, Sigma Aldrich) if they were required for the experiment. Cells were incubated for $24 \mathrm{~h}$ in a $37{ }^{\circ} \mathrm{C}$, humidified incubator with $5 \% \mathrm{CO}_{2}$. The chambers were swabbed to remove cells and Matrigel ${ }^{\mathrm{TM}}$ remaining on the top of the membrane. Cells on the lower side of the membrane were fixed in methanol for $5 \mathrm{~min}$ and stained with $0.5 \%(w / v)$ crystal violet in $12 \%$ glutaraldehyde in water for $15 \mathrm{~min}$. Following a brief $\mathrm{dH}_{2} \mathrm{O}$ wash, cells were counted using Nikon Eclipse T2S phase contrast inverted fluorescence microscope.

\subsection{Intracellular Adenosine Assay}

Cells were plated at $2 \times 10^{4}$ cells per well in tissue culture treated 24 -well plate and allowed to adhere overnight. Adenosine at $500 \mu \mathrm{M}$ was added and incubated for 10, 20, 30, 40, 50 and 60 min before trypsinization. Cell pellets were sonicated to break cell membranes and then centrifuged at $12,000 \times g$ for $10 \mathrm{~min}$ at $4^{\circ} \mathrm{C}$. Supernatant was collected and adenosine levels were measured by using Adenosine Assay Kit (Fluorometric) (ab211094, Abcam, Cambridge, MA, USA) according to manufacturer's protocol.

\subsection{Western Blot Analysis}

A total of $25 \mu \mathrm{g}$ of proteins was separated electrophoretically and transferred to nitrocellulose membrane (10600003, GE, Boston, MA, USA) at $23^{\circ} \mathrm{C}$. Membranes were blocked in blocking buffer $(4 \%$ BSA $w / v$ in TBST), and then incubated with primary antibodies overnight at $4{ }^{\circ} \mathrm{C}$ on a rocking shaker. All antibodies were diluted in blocking buffer (4\% BSA in 0.1\% TBST). Primary antibodies included, 1:1500 phospho-NF-кB p65 (Ser536) (13346, Cell Signaling Technology, Danvers, MA, USA), 1:1500 NF-кB p65 (4764, Cell Signaling Technology), 1:1500 COX2 (12282, Cell Signaling Technology), 1:1500 iNOS (13120, Cell Signaling Technology), 1:1500 cleaved Notch1 (4147, Cell Signaling Technology), AMPK $\alpha$ (5832, Cell Signaling Technology), phospho-AMPK $\alpha$ T172 (2535, Cell Signaling Technology), 1:5000 GAPDH (8884, Cell Signaling Technology) and 1:5000 $\beta$-actin (A2066, Sigma Aldrich). Membranes were incubated for $75 \mathrm{~min}$ on a rocking shaker at $23^{\circ} \mathrm{C}$ with secondary antibodies. Secondary antibodies included 1:5000 goat anti-rabbit IgG conjugated with horseradish peroxidase (7074, Cell Signaling Technology) and 1:5000 horse anti-mouse IgG conjugated with horseradish peroxidase (7076, Cell Signaling Technology). Signal was visualized by autoradiography using enhanced chemiluminescence (ECL) and exposed to Hyperfilm (28906838, GE Healthcare, Boston, MA, USA). Band intensity was analyzed by using ImageJ software (version 1.52a, National Institute of Health, Bethesda, MD, USA).

\subsection{Reverse Transcriptase Polymerase Chain Reaction (RT-PCR)}

Total RNA was extracted using TRIzol reagent (15596-026, Life Technologies, Carlsbad, CA, USA). Following the extraction, RNA was treated with RNAse-free DNase I (04716728001, Roche, Basel, Switzerland). RNA quality and quantity were analyzed spectrophotometrically and electrophoretically. RNA was stained with NovelJuice (LD001-1000, Gendirex, Taoyuan, Taiwan). Following quality and quantity verification, $5 \mu \mathrm{g}$ of total RNA was reverse transcribed using Maloney murine leukemia virus 
(M-MLV) reverse transcriptase (28025-013, Life Technologies). Polymerase chain reaction (PCR) was carried out using helixamp Taq (TBF500N, Nanohelix, Daejeon, South Korea) for 32 cycles with $2 \mathrm{mM}$ $\mathrm{MgCl}_{2}, 0.2 \mathrm{mM} \mathrm{dNTP}, 1 \mu \mathrm{M}$ of forward and reverse primers, $0.025 \mathrm{U} / \mu \mathrm{L}$ of Taq polymerase. Primer sequences are shown in Table S2.

\subsection{Statistical Analysis}

Data were graphed as mean \pm standard deviation (SD). Statistical analyses were performed using ANOVA with Dunnett's test unless otherwise stated. All experiments were performed in at least biological triplicate.

\section{Conclusions}

Adenosine inhibited CCA cell growth and motility in a receptor-independent but ENT-dependent mechanism. The treatment led to an increased intracellular adenosine level, which was further changed to AMP by the activity of adenosine kinase. This conversion of adenosine to AMP is required for the inhibition. This led to an activation of AMPK. Our study provided a novel mechanism underlying CCA cell suppression by adenosine, indicating the therapeutic potential of adenosine for CCA.

Supplementary Materials: Supplementary materials can be found at http://www.mdpi.com/1422-0067/21/3/814/s1.

Author Contributions: Conceptualization, K.L. and J.L.; methodology, K.L. and J.L.; validation, K.L., S.P., N.T. and J.L.; formal analysis, K.L., S.P., N.T. and J.L.; investigation, K.L., S.P., N.T., and J.L.; resources, K.L. and J.L.; writing-original draft preparation, K.L. and J.L.; writing—review and editing, K.L. and J.L.; supervision, J.L.; funding acquisition, J.L. All authors have read and agreed to the published version of the manuscript.

Funding: This study was supported by RD\&E funding (SCH-NR2015-871) from National Science and Technology Development Agency, Thailand, and the CIF grant, Faculty of Science, Mahidol University, Thailand.

Acknowledgments: The authors would like to thank Rutaiwan Tohtong (Mahidol University) for her generosity in providing RMCCA-1 cell line, Stitaya Sirisinha (Chulabhorn Research Institute) for his generosity in providing HuCCA-1 cell line and Banchob Spira (Khon Kaen University) for establishing and commercializing the KKU-100, KKU-055 and KKU-213 cell lines through JCRB cell bank.

Conflicts of Interest: The authors declare no conflict of interest.

\section{Abbreviations}

$\begin{array}{ll}\text { CCA } & \text { Cholangiocarcinoma } \\ \text { ENTs } & \text { Equilibrative nucleoside transporters } \\ \text { imCho } & \text { Immortalized cholangiocytes } \\ \text { NBTI } & \text { S-(4-Nitrobenzyl)-6-thioinosine }\end{array}$

\section{References}

1. Borea, P.A.; Gessi, S.; Merighi, S.; Vincenzi, F.; Varani, K. Pharmacology of Adenosine Receptors: The State of the Art. Physiol. Rev. 2018, 98, 1591-1625. [CrossRef] [PubMed]

2. Chen, J.F.; Eltzschig, H.K.; Fredholm, B.B. Adenosine receptors as drug targets-What are the challenges? Nat. Rev. Drug Discov. 2013, 12, 265-286. [CrossRef] [PubMed]

3. Yu, S.; Hou, D.; Chen, P.; Zhang, Q.; Lv, B.; Ma, Y.; Liu, F.; Liu, H.; Song, E.J.; Yang, D.; et al. Adenosine induces apoptosis through TNFR1/RIPK1/P38 axis in colon cancer cells. Biochem. Biophys. Res. Commun. 2015, 460, 759-765. [CrossRef] [PubMed]

4. Mello Pde, A.; Filippi-Chiela, E.C.; Nascimento, J.; Beckenkamp, A.; Santana, D.B.; Kipper, F.; Casali, E.A.; Nejar Bruno, A.; Paccez, J.D.; Zerbini, L.F.; et al. Adenosine uptake is the major effector of extracellular ATP toxicity in human cervical cancer cells. Mol. Biol. Cell 2014, 25, 2905-2918. [CrossRef]

5. Grenz, A.; Bauerle, J.D.; Dalton, J.H.; Ridyard, D.; Badulak, A.; Tak, E.; McNamee, E.N.; Clambey, E.; Moldovan, R.; Reyes, G.; et al. Equilibrative nucleoside transporter 1 (ENT1) regulates postischemic blood flow during acute kidney injury in mice. J. Clin. Invest. 2012, 122, 693-710. [CrossRef]

6. Abbracchio, M.P.; Burnstock, G. Purinoceptors: Are there families of P2X and P2Y purinoceptors? Pharmacol. Ther. 1994, 64, 445-475. [CrossRef] 
7. Burnstock, G. Purinergic signalling: From discovery to current developments. Exp. Physiol. 2014, 99, 16-34. [CrossRef]

8. Abbracchio, M.P.; Burnstock, G.; Boeynaems, J.M.; Barnard, E.A.; Boyer, J.L.; Kennedy, C.; Knight, G.E.; Fumagalli, M.; Gachet, C.; Jacobson, K.A.; et al. International Union of Pharmacology LVIII: Update on the P2Y G protein-coupled nucleotide receptors: From molecular mechanisms and pathophysiology to therapy. Pharmacol. Rev. 2006, 58, 281-341. [CrossRef]

9. Fredholm, B.B.; AP, I.J.; Jacobson, K.A.; Linden, J.; Muller, C.E. International Union of Basic and Clinical Pharmacology. LXXXI. Nomenclature and classification of adenosine receptors-An update. Pharmacol. Rev. 2011, 63, 1-34. [CrossRef]

10. Khakh, B.S.; Burnstock, G.; Kennedy, C.; King, B.F.; North, R.A.; Seguela, P.; Voigt, M.; Humphrey, P.P. International union of pharmacology. XXIV. Current status of the nomenclature and properties of P2X receptors and their subunits. Pharmacol. Rev. 2001, 53, 107-118.

11. Zhang, J.; Wang, C.; Shi, H.; Wu, D.; Ying, W. Extracellular Degradation Into Adenosine and the Activities of Adenosine Kinase and AMPK Mediate Extracellular NAD(+)-Produced Increases in the Adenylate Pool of BV2 Microglia Under Basal Conditions. Front. Cell Neurosci. 2018, 12, 343. [CrossRef] [PubMed]

12. Nogueira, V.S.; Sebastião, A.M.; Cascalheira, J.F.; Valente, C.A. Role of adenosine on the resistance to an anti-tumor agent in glioblastoma cell lines. Front. Cell Neurosci.. [CrossRef]

13. Zhou, X.T.; Pu, Z.J.; Liu, L.X.; Li, G.P.; Feng, J.L.; Zhu, H.C.; Wu, L.F. Inhibition of autophagy enhances adenosineinduced apoptosis in human hepatoblastoma HepG2 cells. Oncol. Rep. 2019, 41, 829-838. [CrossRef] [PubMed]

14. Nogi, Y.; Kanno, T.; Nakano, T.; Fujita, Y.; Tabata, C.; Fukuoka, K.; Gotoh, A.; Nishizaki, T. AMP converted from intracellularly transported adenosine upregulates p53 expression to induce malignant pleural mesothelioma cell apoptosis. Cell. Physiol Biochem. 2012, 30, 61-74. [CrossRef]

15. Lertsuwan, K.; Peters, W.; Johnson, L.; Lertsuwan, J.; Marwa, I.; Sikes, R.A. Purinergic Receptor Expression and Cellular Responses to Purinergic Agonists in Human Prostate Cancer Cells. Anticancer Res. 2017, 37, 529-537. [CrossRef]

16. Sureechatchaiyan, P.; Hamacher, A.; Brockmann, N.; Stork, B.; Kassack, M.U. Adenosine enhances cisplatin sensitivity in human ovarian cancer cells. Purinergic Signal. 2018, 14, 395-408. [CrossRef]

17. Lertsuwan, J.; Ruchirawat, M. Inhibitory effects of ATP and adenosine on cholangiocarcinoma cell proliferation and motility. Anticancer Res. 2017, 37, 3553-3561. [CrossRef]

18. Sungkasubun, P.; Siripongsakun, S.; Akkarachinorate, K.; Vidhyarkorn, S.; Worakitsitisatorn, A.; Sricharunrat, T.; Singharuksa, S.; Chanwat, R.; Bunchaliew, C.; Charoenphattharaphesat, S.; et al. Ultrasound screening for cholangiocarcinoma could detect premalignant lesions and early-stage diseases with survival benefits: A population-based prospective study of 4,225 subjects in an endemic area. BMC Cancer 2016, 16, 346. [CrossRef]

19. Bergquist, A.; von Seth, E. Epidemiology of cholangiocarcinoma. Best Pract. Res. Clin. Gastroenterol. 2015, 29, 221-232. [CrossRef]

20. Tepsiri, N.; Chaturat, L.; Sripa, B.; Namwat, W.; Wongkham, S.; Bhudhisawasdi, V.; Tassaneeyakul, W. Drug sensitivity and drug resistance profiles of human intrahepatic cholangiocarcinoma cell lines. World. J. Gastroenterol. 2005, 11, 2748-2753. [CrossRef]

21. Marin, J.J.G.; Lozano, E.; Herraez, E.; Asensio, M.; Di Giacomo, S.; Romero, M.R.; Briz, O.; Serrano, M.A.; Efferth, T.; Macias, R.I.R. Chemoresistance and chemosensitization in cholangiocarcinoma. Biochim. Biophys. Acta Mol. Basis Dis. 2018, 1864, 1444-1453. [CrossRef] [PubMed]

22. Sripa, B.; Pairojkul, C. Cholangiocarcinoma: Lessons from Thailand. Curr. Opin. Gastroenterol. 2008, 24, 349-356. [CrossRef] [PubMed]

23. Wijit, A.; Morakote, N.; Klinchid, J. High prevalence of haplorchiasis in Nan and Lampang provinces, Thailand, proven by adult worm recovery from suspected opisthorchiasis cases. Korean J. Parasitol. 2013, 51, 767-769. [CrossRef] [PubMed]

24. Qian, M.B. Clonorchiasis control: Starting from awareness. Infect. Dis. Poverty 2014, 3, 33. [CrossRef]

25. Sithithaworn, P.; Yongvanit, P.; Duenngai, K.; Kiatsopit, N.; Pairojkul, C. Roles of liver fluke infection as risk factor for cholangiocarcinoma. J. Hepatobiliary Pancreat. Sci. 2014, 21, 301-308. [CrossRef]

26. Lim, J.H. Liver flukes: The malady neglected. Korean J. Radiol. 2011, 12, 269-279. [CrossRef] 
27. Nam, J.H.; Moon, J.H.; Kim, I.K.; Lee, M.R.; Hong, S.J.; Ahn, J.H.; Chung, J.W.; Pak, J.H. Free radicals enzymatically triggered by Clonorchis sinensis excretory-secretory products cause NF-kappaB-mediated inflammation in human cholangiocarcinoma cells. Int. J. Parasitol. 2012, 42, 103-113. [CrossRef]

28. Ishimura, N.; Bronk, S.F.; Gores, G.J. Inducible nitric oxide synthase up-regulates Notch-1 in mouse cholangiocytes: Implications for carcinogenesis. Gastroenterology 2005, 128, 1354-1368. [CrossRef]

29. Morell, C.M.; Strazzabosco, M. Notch signaling and new therapeutic options in liver disease. J. Hepatol. 2014, 60, 885-890. [CrossRef]

30. Pinlaor, S.; Hiraku, Y.; Yongvanit, P.; Tada-Oikawa, S.; Ma, N.; Pinlaor, P.; Sithithaworn, P.; Sripa, B.; Murata, M.; Oikawa, S.; et al. iNOS-dependent DNA damage via NF-kappaB expression in hamsters infected with Opisthorchis viverrini and its suppression by the antihelminthic drug praziquantel. Int. J. Cancer 2006, 119, 1067-1072. [CrossRef]

31. Salvestrini, V.; Orecchioni, S.; Talarico, G.; Reggiani, F.; Mazzetti, C.; Bertolini, F.; Orioli, E.; Adinolfi, E.; Di Virgilio, F.; Pezzi, A.; et al. Extracellular ATP induces apoptosis through P2X7R activation in acute myeloid leukemia cells but not in normal hematopoietic stem cells. Oncotarget 2017, 8, 5895-5908. [CrossRef] [PubMed]

32. Souza, C.O.; Santoro, G.F.; Figliuolo, V.R.; Nanini, H.F.; de Souza, H.S.; Castelo-Branco, M.T.; Abalo, A.A.; Paiva, M.M.; Coutinho, C.M.; Coutinho-Silva, R. Extracellular ATP induces cell death in human intestinal epithelial cells. Biochim. Biophys. Acta 2012, 1820, 1867-1878. [CrossRef] [PubMed]

33. Seubwai, W.; Wongkham, C.; Puapairoj, A.; Khuntikeo, N.; Pugkhem, A.; Hahnvajanawong, C.; Chaiyagool, J.; Umezawa, K.; Okada, S.; Wongkham, S. Aberrant expression of NF-kappaB in liver fluke associated cholangiocarcinoma: Implications for targeted therapy. PLoS ONE 2014, 9, e106056. [CrossRef]

34. Seubwai, W.; Vaeteewoottacharn, K.; Kraiklang, R.; Umezawa, K.; Okada, S.; Wongkham, S. Inhibition of NF-kappaB Activity Enhances Sensitivity to Anticancer Drugs in Cholangiocarcinoma Cells. Oncol. Res. 2016, 23, 21-28. [CrossRef]

35. Lustri, A.M.; Di Matteo, S.; Fraveto, A.; Costantini, D.; Cantafora, A.; Napoletano, C.; Bragazzi, M.C.; Giuliante, F.; De Rose, A.M.; Berloco, P.B.; et al. TGF-beta signaling is an effective target to impair survival and induce apoptosis of human cholangiocarcinoma cells: A study on human primary cell cultures. PLoS ONE 2017, 12, e0183932. [CrossRef]

36. Lertsuwan, J.; Lertsuwan, K.; Sawasdichai, A.; Tasnawijitwong, N.; Lee, K.Y.; Kitchen, P.; Afford, S.; Gaston, K.; Jayaraman, P.S.; Satayavivad, J. CX-4945 Induces Methuosis in Cholangiocarcinoma Cell Lines by a CK2-Independent Mechanism. Cancers 2018, 10, 283. [CrossRef]

37. Zakharia, K.; Miyabe, K.; Wang, Y.; Wu, D.; Moser, C.D.; Borad, M.J.; Roberts, L.R. Preclinical In Vitro and In Vivo Evidence of an Antitumor Effect of CX-4945, a Casein Kinase II Inhibitor, in Cholangiocarcinoma. Transl. Oncol. 2019, 12, 143-153. [CrossRef]

38. Liu, S.; Jiang, J.; Huang, L.; Jiang, Y.; Yu, N.; Liu, X.; Lv, Y.; Li, H.; Zou, L.; Peng, C.; et al. iNOS is associated with tumorigenicity as an independent prognosticator in human intrahepatic cholangiocarcinoma. Cancer Manag. Res. 2019, 11, 8005-8022. [CrossRef]

39. Ohira, M.; Yoshizumi, T.; Yugawa, K.; Kosai-Fujimoto, Y.; Inokuchi, S.; Motomura, T.; Mano, Y.; Toshima, T.; Itoh, S.; Harada, N.; et al. Association of inflammatory biomarkers with long-term outcomes after curative surgery for mass-forming intrahepatic cholangiocarcinoma. Surg. Today 2019. [CrossRef]

40. Svinarenko, M.; Katz, S.F.; Tharehalli, U.; Mulaw, M.A.; Maier, H.J.; Sunami, Y.; Fischer, S.K.; Chen, Y.; Heurich, S.; Erkert, L.; et al. An IKK/NF-kappaB Activation/p53 Deletion Sequence Drives Liver Carcinogenesis and Tumor Differentiation. Cancers 2019, 11, 1410. [CrossRef]

41. Camici, M.; Garcia-Gil, M.; Tozzi, M.G. The Inside Story of Adenosine. Int. J. Mol. Sci. 2018, $19,784$. [CrossRef]

42. Hardie, D.G.; Ross, F.A.; Hawley, S.A. AMPK: A nutrient and energy sensor that maintains energy homeostasis. Nat. Rev. Mol. Cell Biol. 2012, 13, 251-262. [CrossRef] [PubMed]

43. Masse, K.; Bhamra, S.; Allsop, G.; Dale, N.; Jones, E.A. Ectophosphodiesterase/nucleotide phosphohydrolase (Enpp) nucleotidases: Cloning, conservation and developmental restriction. Int. J. Dev. Biol. 2010, 54, 181-193. [CrossRef] [PubMed]

44. Covarrubias, R.; Chepurko, E.; Reynolds, A.; Huttinger, Z.M.; Huttinger, R.; Stanfill, K.; Wheeler, D.G.; Novitskaya, T.; Robson, S.C.; Dwyer, K.M.; et al. Role of the CD39/CD73 Purinergic Pathway in Modulating Arterial Thrombosis in Mice. Arterioscler. Thromb. Vasc. Biol. 2016, 36, 1809-1820. [CrossRef] [PubMed] 
45. Bastin-Coyette, L.; Smal, C.; Cardoen, S.; Saussoy, P.; Van den Neste, E.; Bontemps, F. Mechanisms of cell death induced by 2-chloroadenosine in leukemic B-cells. Biochem. Pharmacol. 2008, 75, 1451-1460. [CrossRef]

46. Sripa, B.; Leungwattanawanit, S.; Nitta, T.; Wongkham, C.; Bhudhisawasdi, V.; Puapairoj, A.; Sripa, C.; Miwa, M. Establishment and characterization of an opisthorchiasis-associated cholangiocarcinoma cell line (KKU-100). World. J. Gastroenterol. 2005, 11, 3392-3397. [CrossRef]

47. Sirisinha, S.; Tengchaisri, T.; Boonpucknavig, S.; Prempracha, N.; Ratanarapee, S.; Pausawasdi, A. Establishment and characterization of a cholangiocarcinoma cell line from a Thai patient with intrahepatic bile duct cancer. Asian Pac. J. Allergy Immunol. 1991, 9, 153-157.

48. Rattanasinganchan, P.; Leelawat, K.; Treepongkaruna, S.A.; Tocharoentanaphol, C.; Subwongcharoen, S.; Suthiphongchai, T.; Tohtong, R. Establishment and characterization of a cholangiocarcinoma cell line (RMCCA-1) from a Thai patient. World. J. Gastroenterol. 2006, 12, 6500-6506. [CrossRef]

C 2020 by the authors. Licensee MDPI, Basel, Switzerland. This article is an open access article distributed under the terms and conditions of the Creative Commons Attribution (CC BY) license (http://creativecommons.org/licenses/by/4.0/). 